\section{Military Service and the Professional Institutions}

STEPS havo been taken to ensure that membors of all classes of the leading engineering and professional institutions, when called up for military service, will be posted to units in which their services will be best employed in the national interest and, in the case of graduntes and students, to units in which the training will bo of use to them on returning to civilian work. Members of engineering institutions should mention the fact when supplying particulars of their qualifications to 'interviewing' officers; a letter stating class of membership should be obtained from the Institution concerned for presentation to the officer.

\section{Modern Wireless Communications}

In response to a request and with the view of meeting the needs of students and others who may wish to qualify for possible futuro service in the uniformed and non-uniformed radio branches of the Defence Forces, arrangements havo been made by the Royal Institution for a series of lectures on modern wireless communications. Tho course will consist of twelve afternoon lectures, commencing on October 31 , and will bo given by Prof. C. L. Fortescue, Dr. R. I. Smith-Rose and Dr. E. V. Appleton. They will deal with important aspects of the installations, transmission of the signals and the phenomena of radio wave propagation. Tickets, for which there will bo no charge, may be obtained from the General Secretary, Royal Institution, Albemarlo Street, London, W.1.

\section{The British Empire Naturalists' Association}

THE British Empiro Naturalists' Association has decided to suspend further publication of its quarterly journal Country-Side during the war, but in order to continue the maximum amount of activities, full power has been given to the rarious branches to carry on under their own organization until such times as normal conditions return. There will be circulated, however, the usual quarterly issues of the Branch $N^{r}$ eus, in order to keep branches in contact with headquarters. The decision was made not without regrets, but the view maintained was that by conserving funds now, the Association would bo in a stronger position to resume its full activities when peace returns, rather than to weaken itself by struggling against the rising costs and difficulties of voluntary labour. Numerous provincial natural history societies have cancelled their programmes, and others have adopted a method of meeting in the afternouns.

\section{Institute of Metals}

Durisa the War the Institute of Metals is continu. ing its activities; other than those of a social character. Tho headquarters in Grosvenor Gardens, London, remain open, and the Joint Library and the Information Department are available to members. The Monthly Journal will continuo to publish original papers, and also to provide abstracts, the importance of which becomes more apparent as members find it difficult to obtain access to technical journals.

\section{Royal Geographical Society}

Tre Royal Geographical Society will, so long as is possible, carry out its programme of meetings for the session, but at modified times. All meotings will be at 5 p.m.; the evening meeting programmo on alternate Mondays, the afternoon meeting and geographical films programme on the intermediate Mondays. At the first meeting, on Monday, October 30 at 5 p.m., Mr. F. Kingdon Ward will read a paper on "Six Months in the Assam Himalaya". Tho Asia Lecture will be delivered by Dr. G. MI. Isees on November 27.

\section{Announcements}

IIr. Percy R. Lowe has been awarded the Vorner von Heidstam Gold Medal of the Royal Swedish Academy of Sciences in recognition of his "important and successful endeavours to further the protection of the world's fauna, endeavours of great benofit also to the migratory birds of Sweden".

AT the annual statutory meeting of the Royal Society of Edinburgh held on October 23, the following officers wero elected: President; Prof. E. T. Whittaker; Vice.Presidents, Principal J. C. Smail, Prof. J. Walton, Dr. James Watt, Dr. Iseonard Dobbin, Mr. J. A. Inglis and Prof. R. Stockman; General Secretary, Prof. James P. Kendall ; Secretaries to the Ordinary Meetings, Dr. A. C. Aitken and Prof. R.J.D. Graham; Treasurer, Dr. E. M. Wedderburn ; Curator of the Library and Museum, Dr. J. E. Mackenzie.

Tre Rockefeller Foundation has recontly awarded two grants, of 350,000 and 90,000 dollars, to the Johns Hopkins University School of Medicine, Baltimore. The larger sum is to be used over a ten-year period to equip and maintain a department of preventive medicine, while the second grant will bo utilized as a research fund to bo distributed among departments and to projects which stand in greatest need of carrying out research programmes.

Messis. Flatters. and Garnett, Lttd., 309 Oxford Road, Manchester, 13, have issued an abridged list of their microscopo slides, dealing chiefly with biological subjects. This includes two sets, of thirty-six slides each, suitable for the zoology and botany respectively of Higher School Cortificato and lst M.B. students. The firm has a stock of 30,000 slides; no change has been made in prices.

Prof. S. Chupsux has noted some misprints in his articlo on the meeting of the International Union of Geodesy and Geophysics published in NATURE of October 21 : p. 717, col. 1, line 10 from bottom, for "Signole" read "Signore"; line 9 from bottom, for "Lütschy" read "Lütschg"; p. 718, col. 2, line 5 from end of article, for "Sánchey" read "Sánchez". $\mathrm{He}$ also intended to emphasizo the completo absonco of French and Italian delegates and of Russian visitors, referred to in the article. 